\title{
New Insights into the Adrenocortical Accumulation of Lipofuscin
}

\author{
Behling Cheng* \\ Biochemistry Department, Kuwait University Health Science Center, Kuwait
}

Submission: March 21, 2017; Published: May 02, 2017

*Corresponding author: Behling Cheng, Biochemistry Department, Faculty of Medicine, Kuwait University Health Science Center, P. 0. Box 24923, Safat 13110, Kuwait, Email: Behling@hsc.edu.kw

\section{Introduction}

Adrenocortical zona reticularis of aged rats accumulates lipofuscin granules, but the mechanism of the formation has not been established.ACTH stimulation is a major factor that affects the accumulation.

\section{Discussion}

Rat adrenal cortex comprises three zones of steroidogenic tissues: glomerulosa (ZG), fasciculata (ZF) and reticularis (ZR). The ZG synthesizes mineralocorticoid (aldosterone) in response to low $\mathrm{Na}+$ or high $\mathrm{K}+$ in circulation. In parallel, the $\mathrm{ZF}$ and ZR synthesize glucocorticoid (corticosterone) responding to stimulation by the pituitary hormone ACTH. Prolonged ACTHstimulation of rats induces transformation of ZG-cells to ZF-like cellsto maximize the production of corticosterone [1]

The morphological appearance of the three adrenocortical zones has been theorized by a centripetal migration of glomerular cells. Diderholm and Hellman [2] studied 3H-thymidinelabeled cells (at the S-phase) in rat adrenals and found that four hours after the thymidine injection, the labeled cells were first localized to the capsule, ZG, and the outer parts of the ZF. After two months, the labeled cells were found within the ZR. Furthermore, the labeled cells reach the ZR where they ultimately become apoptotic. The loss of ZR cells is considered as a prerequisite of the centripetal migration theory for renewal of adrenocortical cells [3]. Zajicek et al. [4] and Huang et al. [5] proposed that the cell migration is derived from sub-capsular and capsular stem cells. Using a 'lineage-tracing technique', Freedman et al. [6] demonstrated that, mouse adrenocortical zonation occurs when differentiated G-cells undergo centripetal migration and lineage conversion into F-like cells during postnatal development. The migration is a slow process which takes weeks to months, and the lineage conversion process is Steroidogenic Factor 1 (SF-1)dependent. However, following SF-1-knockout, fully functional F-cells are still maintained. This observation demonstrates that a G-cell independent mechanism also exists, perhaps through an activation process of progenitor cells in ZF under the circumstance. Our recent findings [7] indicate that ACTH stimulation can accelerate the rat centripetal migration process. This is based on the observation that the immunostains of aldosterone synthase were originally concentrated in the rat adrenocortical ZG, but became scattering in the ZR after ACTH stimulation for four consecutive days.

Adrenal steroid hormones are derived from cholesterol. Thus, adrenocortical cells develop effective mechanisms with which cholesterol is taken up from plasma lipoproteins for steroidogenesis, and excessive cholesterol is either stored in cytosolic lipid droplets or released back to circulation via an ATPbinding cassette $(\mathrm{ABC})$ transporter-mediated process, commonly referred as "cholesterol efflux." Rat adrenal cortex expressesliverX-receptor (LXR) [8] and retinoid-X-receptors (RXR) $\alpha$ and $\beta$ [9]. LXR/RXR heterodimer enhances the expression of ABCA1 and ABCG1 [10]. We have found that ACTH-stimulation affectsthe male Wistar rat adrenal ABCA1 and ABCG1 protein levels and their glandular distributions (unpublished observations).

$\mathrm{n}$ this context, the pathogenic mechanism of the human Stargardt Disease is believed to be associated with the disorder of ABCR (ABCA4) in the discs of the outer rod segments which consequently leads to the formation of A2E (a pyridinium bisretinoid) [11]. A2E is a major component of lipofuscin and is toxic to retinal pigment epithelium (RPE). The accumulation of A2E causes RPE cell apoptosis, thereby explaining age-related macular degeneration and macular degeneration characteristic of Stargardt Disease.However, Crouch et al. [12] recently reported that the accumulation of $\mathrm{A} 2 \mathrm{E}$ is not responsible for the increase in lipofuscin fluorescence observed in the central RPE with aging in humans, but is correlated well in all the mouse models.

Aged rat adrenocortical ZR accumulates a large amount of lipofusicn. We have reported that aging in the male F344 rats is 
accompanied by accumulations of cholesterol esters [13] and retinyl stearate [14] in addition to lipofuscinin the adrenal glands. Prolonged stimulation of the rats with ACTH for seven days causes reduced adrenocortical accumulations of retinal stearate fluorescence [14] and lipofuscin accumulation [15]. These facts collectively indicate that adrenocortical accumulation of lipofuscin in the aged rat (never been experimentally stimulated) may be a result of lacking ACTH stimulation during the captivity.

\section{Conclusion}

The accumulation of lipofuscin granules in the adrenocortical zona reticularis of unstimulated aged rats is likely associated with "lacking of ACTH stimulation" during their captivities.

\section{Acknowledgement}

This work is dedicated to the memory of the late Professor Jerome Kowal, who stimulated my interest in studying aging. The author thanks Ms. Fatima Sequeira for her proofreading of the manuscript.

\section{References}

1. Ho MM, Vinson GP (1993) 11 beta-Hydroxylase gene expression in the rat adrenal cortex. J Endocrinol 139(2): 301-306.

2. Diderholm H, Hellman B (1960) The Cell migration in the adrenal cortex of rats studied with tritiated thymidine. Acta Physiol Scand 50: 197-202.

3. Wright NA, Voncina D, Morley AR (1973) An attempt to demonstrate cell migration from the zona glomerulosa in the prepubertal male rat adrenal cortex. J Endocrinol 59(3): 451-459.

4. Zajicek G, Ariel I, Arber N (1986) The streaming adrenal cortex: direct evidence of centripetal migration of adrenocytes by estimation of cell turnover rate. J Endocrinol 111(3): 477-482.
5. Huang CC, Miyagawa S, Matsumaru D, Parker KL, Yao HH (2010) Progenitor Cell Expansion and organ size of mouse adrenal is regulated by sonic hedgehog. Endocrinology 151(3): 1119-1128.

6. Freedman BD, Kempna PB, Carlone DL, Shah MS, Guagliardo NA, et al. (2013) Adrenocortical zonation results from lineage conversion of differentiated zona glomerulosa cells. Dev Cell 26(6): 666-673.

7. Cheng B, Kilarkaje N, Iskandarani IN, Al-Asfoor AA, Sequeira F, et al. (2016) Does repetitive stimulation of the rat with ACTH accelerates migration of adrenocortical glomerulosa cells? The $6^{\text {th }}$ International Congress on Diabetes and Endocrinology, Dallas, USA.

8. Cummins CL, Volle DH, Zhang Y, McDonald JG, Sion B, et al. (2006) Liver $\mathrm{X}$ receptors regulate adrenal cholesterol balance. J Clin Invest 116(7): 1902-1912.

9. Cheng B, Al-Shammari FH, Ghader IA, Sequeira F, Thakkar J, et al. (2017) Fundamental studies of adrenal retinoid-X-receptor: protein isoform, tissue expression, subcellular distribution and ligand availability. J Steroid Biochem Mol Biol pii: S0960-0760(17)30067-5.

10. Murthy S, Born E, Mathur SN, Field FJ (2002) LXR/RXR activation enhances basolateral efflux of cholesterol in CaCo-2 cells. J Lipid Res 43(7): 1054-1064.

11. Wolf G (2003) Lipofuscin and Macular Degeneration. Nutr Rev 61(10): $342-346$.

12. Crouch RK, Koutalos Y, Kono M, Schey K, Ablonczy Z (2015) A2E and Lipofuscin in Molecular Biology of Eye Disease, Chapter 26, Progress in Molecular Biology and Translational Science 134(449-463).

13. Cheng B, Kowal J (1994) Adrenal aging: accumulation of cholesteryl esters and lipofuscin granules. Endocrine 2: 1097-1106

14. Cheng B, Tserng KY, Kowal J, Buekers KS, Abraham S, (1996) Characterization and identification of adrenal age-related non-polar fluorescent substance. Endocrinology 137(6): 2447-2456.

15. Cheng B, Hornick TR, Hassan MO, Chou SC, Abraham S, et al. (1999) Effects of prolonged ACTH-stimulation on adrenocortical accumulation of lipofuscin granules in aged rats. Tissue Cell 31(6): 594-604.

\section{Your next submission with Juniper Publishers will reach you the below assets}

- Quality Editorial service

- Swift Peer Review

- Reprints availability

- E-prints Service

- Manuscript Podcast for convenient understanding

- Global attainment for your research

- Manuscript accessibility in different formats

( Pdf, E-pub, Full Text, Audio)

- Unceasing customer service

Track the below URL for one-step submission https://juniperpublishers.com/online-submission.php 